\title{
Checkmate at the Check-In. Discrimination or Transatlantic People Smuggling from Brussels National Airport
}

\author{
WENDY DE BONDT \& NELE AUDENAERT ${ }^{\star}$
}

\section{The American Travel Ban: Legal or Just Ethical and Practical Concerns?}

Donald Trump has been the talk of the town all over the world on quite some occasions. This contribution looks into the fuzz caused by his so-called Muslim ban or the travel ban for terrorists. ${ }^{1}$ Nationals from Iran, Libya, Somalia, Sudan and Yemen were denied access to US territory because they were considered a threat. That threat is based on their countries of origin as those are considered (i) to be financing terrorist organisations, (ii) are limited in their day to day functioning by terrorist organisations or (iii) find themselves confronted with active conflict areas within their boundaries, effectively

* Respectively, professor and PhD Researcher, both members of the Institute for International Research on Criminal Policy, Ghent University.

1 The White House, Executive Order 13769, Protecting the nation from foreign terrorist entry into the United States, 27 January 2017. Full text can be consulted on https://www.whitehouse. gov/the-press-office/2017/01/27/executive-order-protecting-nation-foreign-terrorist-entryunited-states (last consultation 25 January 2018). Later replaced by The White House, Executive Order 13780, Protecting the nation from foreign terrorist entry into the United States, 6 March 2017. Full text can be consulted on https://www.whitehouse.gov/the-press-office/2017/03/06/ executive-order-protecting-nation-foreign-terrorist-entry-united-states (last consultation 25 January 2018).

This is an Open-access article distributed under the terms of the Creative Commons Attribution 3.0 Unported License (http://creativecommons.org/licenses/ by/3.0/), permitting all use, distribution, and reproduction in any medium, provided the original work is properly cited. 
limiting them in their ability to share the necessary information on potential travellers. ${ }^{2}$ The existence of any concrete indication of potential involvement in - let alone conviction for - participation in terrorist activities for each of the individually refused travellers was not required. Each of the nationals of the listed countries are banned automatically as a precaution measure.

Immediately after the publication of the presidential executive orders, ethical objections and legal concerns were voiced. Many felt the generalisation of the potential danger ${ }^{3}$ to the entire population of a country was inacceptable. ${ }^{4}$ Within the United States, several alarm bells went off and different legal procedures were started. ${ }^{5}$ As a consequence thereof, the effect of the presidential executive order was suspended. ${ }^{6}$

Meanwhile, the aviation sector was not pleased with being instrumentalised to execute the controversial travel ban, suspended or not. From their side, however - deduced from

2 Original text: 'Each of these countries is a state sponsor of terrorism, has been significantly compromised by terrorist organizations or contains active conflict zones. Any of these circumstances diminishes the foreign government's willingness or ability to share or validate important information about individuals seeking to travel to the United States. Moreover, the significant presence in each of these countries of terrorist organizations, their members, and others exposed to those organizations increases the chances that conditions will be exploited to enable terrorist operatives or sympathizers to travel to the United States' (The White House, Executive Order 13780).

3 It was argued that the problematic situation in which these governments had to operate, makes it impossible to guarantee the availability of the necessary documents needed for the security checks performed by the American Immigration Services.

4 See amongst others Spiegel and Rubenstein, The academic case for repealing Trump's refugee and travel ban, 389 The Lancet (2017) pp. 679-680; Ardehali, Potential consequences of the immigration ban on the scientific community, 127(3) The Journal of Clinical Investigation (2017) pp. 735-736.

5 On 30 January 2017, Washington initiated a procedure against Executive Order 13769 at the US District Court in Seattle. Minnesota was not far behind, almost immediately joining the procedure as a co-applicant. Several other states and (technology) companies (amongst others Google) announced their support for the procedure. Soon thereafter, also Massachusetts started a legal procedure. See amongst others: http://www.lexology.com/library/detail.aspx?g=46667476795e-4a42-8a3a-a5561532dcbb (last consultation 25 January 2018) and http://edition.cnn. com/2017/02/03/politics/federal-judge-declines-to-renew-restraining-order-on-trumptravel-ban/ (last consultation 25 January 2018). It came as no surprise that the State of Hawaii announced on 8 March 2017 to start legal proceedings against the new travel ban. See amongst others: http://deredactie.be/cm/vrtnieuws/buitenland/2.48392 (last consultation 25 January 2018) and http://www.demorgen.be/buitenland/hawaii-vecht-nieuw-inreisverbod-trump-aanb478424e/ (last consultation 25 January 2018).

6 United States District Court, Western District of Washington 3 February 2017, C-2:17-cv00141-JLR, State of Washington vs. Trump, http://edition.cnn.com/2017/02/03/politics/federaljudge-temporarily-halts-trump-travel-ban-nationwide-ag-says/index.html (last consultation 25 January 2018), as confirmed by the United States Court of Appeals for the Ninth Circuit 9 February 2017, C 17-35105, State of Washington vs. Trump, https://www.scribd.com/ document/338917426/Motion-for-stay-9th-Circuit-Order-9-February-2017\#download\&from_ embed (last consultation 25 January 2018). 
the positions voiced in different media - the concerns seemed first and foremost to be of a practical nature. Since they were not given any heads up on the publication of the first executive order, they saw themselves confronted with significant practical challenges to put additional checks in place in order to obey and give effect to the travel ban.

More fundamental, however, was the question put forward by some airlines, so as to whether, on top of the practical concerns they had, they should also have legal concerns in light of their responsibilities and duties towards their passengers. Some airlines questioned what the impact of the executive order would be, looking at it through a criminal law lens. Based on the very specific questions we received from an airline operating amongst others from Brussels National Airport, we will look into (i) the extent to which obeying the order and thus leaving passengers behind could amount to a form of discrimination constituting an offence in Belgian criminal law, (ii) the extent to which ignoring the order and thus accepting passengers on the flights could amount to a form of people smuggling, and (iii) whether there is a legal defence available that could prevent the airline from committing a criminal offence. ${ }^{7}$ Though the questions were raised by one airline company, the answers are valid for all airlines (including e.g. SAS Scandinavian Airline Systems) operating from Belgian airports. More broadly, this case should open discussions on the criminal law impact in other European jurisdictions, in light of applicable European law. It is a way to urge policy makers to provide a more clear legal framework for companies (in general) who find themselves confronted with legal and/ or policy based inconsistencies or even incompatibilities between different jurisdictions.

\section{Discrimination: Distinguishing Based on Nationality}

\subsection{In Search of an Applicable Legal Basis}

First and foremost, we will look into the airline's concerns related to the applicability of the Belgian anti-racism legislation ${ }^{8}$ when it operated from Brussels National Airport. ${ }^{9}$ In light thereof, it should first be assessed whether the airline company would fall within the scope of application of that legislation. The scope of the legislation is described in article

7 Those questions were put to us by the legal service of an airline company that operates, amongst others, from Brussels National Airport.

8 Law of 30 July 1981 concerning the punishment of acts induced by racism or xenophobia (original title: wet tot bestraffing van bepaalde door racisme of xenofobie ingegeven daden), Belgian Official Journal, 8 August 1981, at 9928, as amended by Law of 10 May 2007 amending the law of 30 July 1981 concerning the punishment of acts induced by racism or xenophobia (original title: wet tot wijziging van de wet van 30 juli 1981 tot bestraffing van bepaalde door racisme of xenofobie ingegeven daden), Belgian Official Journal, 30 May 2007, at 29046.

9 Brussels National Airport is used as an example. The reasoning is valid for all Belgian Airports. 
$5, \S 1,1^{\circ}$ of the Anti-Racism Law, and stipulates that it is applicable to all persons, both natural and legal, both public and private sector, in their activities that relate to the access to' and 'the offering of' services that are publically available. That description clarifies that airlines operating from Brussels National Airport fall within its scope of application and have to abide by its rules, amongst which is the prohibition to discriminate based on nationality.

Since the question related to a company operating from Brussels National Airport, the Belgian anti-racism legislation is used as a basis to develop the argumentation. It is not so self-evident as one may expect to make the concern valid for airline companies operating from any of the European airports, regardless of the specificity of the underlying domestic legislation, since it is not easy to find a strong legal basis that provides for a European level prohibition of discrimination based on nationality in this context.

At EU level, the concept of discrimination based on nationality is inconsistently defined, in that it sometimes is and sometimes is not included in racial discrimination. Firstly, some instruments include discrimination based on nationality in racial discrimination. Article 1.1 of the Framework Decision 2008/913/JHA on Racism and Xenophobia stipulates that it should be an offence to 'publicly incite to violence or hatred directed against a group of persons or a member of such a group defined by reference to race, colour, religion, descent or national or ethnic origin. ${ }^{10}$ Given that the acts required by the travel ban are directed against a group of persons defined by reference to nationality, the acts against them could fall within its scope. The crucial question here is whether giving effect to a travel ban would amount to the level of publicly inciting to hatred, based on the generalised perception of dangerousness of those persons. It is not unlikely that a judge would be of the opinion that the acts underlying the current case would not be severe enough to rise to that level. However, a different ruling might not be totally excluded either. Secondly, other instruments exclude discrimination based on nationality from racial discrimination. The 2000 EU Directive on Racial Discrimination stipulates in its article 2 that the principle of equal treatment shall mean that there shall be no direct or indirect discrimination based on racial or ethnic origin. Article 3 continues that there shall be no discrimination in relation to access to and supply of goods and services which are available to the public, including housing. So far so good. However, in fine it is stipulated that the Directive does not cover difference of treatment based on nationality. Nationality discrimination is regulated under the Free Movement Directive ${ }^{11}$. Given that free movement rights specifically target EU citizens, the group targeted by the travel ban cannot rely on those provisions. In terms of introducing a general prohibition

10 Framework Decision 2008/913/JHA of 28 November 2008 on combating certain forms and expressions of racism and xenophobia by means of criminal law, O.J. L 328/55 of 6/12/2008.

11 Directive 2004/38/EC on the right of citizens of the Union and their family members to move and reside freely within the territory of the Member States, O.J. L 158/77 of 30.4.2004. 
on discrimination based on nationality, there is ample room for maturing in the EU's discrimination legislation.

Whereas provisions in Council of Europe instruments may be wider in scope in that they apply to all citizens in the jurisdiction of the Member States, regardless of the individual nationality, some provisions are also limited in scope in a different way. Reference can be made to the non-discrimination provisions included in the European Convention on Human Rights. Article 14 ECHR clearly stipulates that only 'the enjoyment of the rights and freedoms set forth in this Convention, shall be secured without discrimination on any ground such as ... national or social origin .... The non-discrimination provision does not apply to any rights or freedoms with a different legal basis. Fortunately, the scope of the discrimination prohibition is generalised in Protocol 12 to the ECHR. Article 1.1 of that protocol stipulates that 'the enjoyment of any right set forth by law shall be secured without discrimination on any ground such as ... national or social origin ...' ${ }^{12}$ The Commentary also states that while the Protocol principally protects individuals against discrimination 'from the State', it will also relate to those relations between private persons, which the State is normally expected to regulate, 'for example, arbitrary denial of access to work, access to restaurants, or to services which private persons may make available to the public such as medical care or utilities such as water and electricity. ${ }^{13}$ Broadly speaking, Protocol 12 will prohibit discrimination outside purely personal contexts, where individuals exercise functions placing them in a position as to decide on how publicly available goods and services are offered. The protection offered by the protocol can be enjoyed by all those within the jurisdiction of a Member State, in their relationship with amongst others airline companies. Unfortunately, however, the instrument is poorly signed and ratified in general, ${ }^{14}$ including in the Scandinavian countries. ${ }^{15}$ This means that even at the Council of Europe level, there is significant room for improvement when it comes to generalising the prohibition to discriminate based on the nationality of persons.

\subsection{On Direct and Indirect Ways to Discriminate}

Though - in this case - the ban is inherently linked to the nationality of the passenger, the nationality as such will not be the reason why the airline denies a passenger access to the plane. The access will be denied because the passenger is not in the possession

12 Protocol nr. 12 to the Convention for the Protection of Human Rights and Fundamental Freedoms, Rome 4 November 2000.

13 Explanatory Report, para. 28. Available at: http://conventions.coe.int/Treaty/en/Reports/ Html/177.htm (last consultation 25 January 2018).

14 At the beginning of 2018 , it is only applicable in 17 out of the $47 \mathrm{CoE}$ countries.

15 Sweden and Denmark have not signed the instrument. Norway and Iceland have only signed the instrument. Finland is the only country to have signed and ratified. 
of the travel documents needed to enter the destination country. Passengers that are a national of Iran, Libya, Somalia, Sudan, Syria or Yemen, will not be in the possession of the required travel documents to enter the United States. From that perspective, there is no direct discrimination based on the nationality of the passengers. It is argued that the criterion of having the required travel documents is a neutral criterion that applies to all passengers, regardless of their nationality. In light thereof, airlines will be able to successfully argue that denying access to the flight is not a form of direct discrimination based on nationality.

However, even though nationality may not be the criterion used by the airline, that does not mean that denying access to the flight cannot be labelled as so-called indirect distinction based on nationality. Pursuant to article $4,8^{\circ}$ of the Anti-Racism Law, an indirect distinction based on nationality is defined as the situation that occurs when a seemingly neutral provision would result in a disadvantage, especially for people that meet one of the protected criteria, among which nationality is listed. Denying access to people who are not in the possession of the required travel documents would most likely be qualified as such a seemingly neutral provision. The disadvantage itself does not need to be significant. The existing European case law has clarified that what needs to be significant is for people of the protected group to experience the disadvantage. ${ }^{16}$ Even though people with a different nationality may also not be able to meet the criterion of having the necessary travel documents, it is clear that the nationals of the six listed states have a significantly higher risk than people from any other nationality as they will never be able to meet that requirement. ${ }^{17}$ The rule will result in a situation where people of a certain nationality will be confronted with a refusal rate of $100 \%$ whereas people of a different nationality will have a significantly lower refusal rate.

\subsection{The Absence of a 'Legal Defence': Many Pieces of the Same Puzzle?}

Making an indirect distinction that is felt significantly more by a group of a certain nationality does not necessarily amount to a punishable form of discrimination. Making

16 Case C-83/16, CHEZ Razpredelenie Bulgaria AD v. Komisia za zashtita ot diskriminatsia, para. 98-99; See also case law of the Court of Justice of the European Union in which measures that would impact upon foreign workers more than national workers, were qualified as indirect discrimination: Case C-237/94, John O’Flynn v. Adjudication Officer, para. 20; O.J. L 180/1, Council Directive 2000/43/EC of 29 June 2000 implementing the principle of equal treatment between persons irrespective of racial or ethnic origin, Brussels, 19 July 2000, Article 2, lid 2, b).

17 See for the same reasoning: Bell, Anti-discrimination law and the European Union (Oxford University Press 2002) at 34; Tobler, Indirect discrimination. A Case study into the Development of the Legal Concept of Indirect Discrimination under EC Law (Intersentia 2005) at 57. 
an indirect distinction only amounts to a punishable form of discrimination in absence of a legal defence. ${ }^{18}$

The quest to alleviate the airlines of their concerns therefore continues with an analysis of the possibly applicable legal defences. It turns out that finding the pieces of that puzzle is far from self-explanatory. Title II of the Anti-Racism Law makes reference to two different legal defences. First, article 9 of that law stipulates that there is a defence if the indirect distinction is made to reach 'a legitimate goal' and within the boundaries of what is appropriate and necessary to reach that goal. Although, unfortunately in the preparatory works, there are no guidelines provided on how to interpret 'a legitimate goal', it should be interpreted in a restrictive fashion, given that the law aims to protect people from being discriminated. Only exceptional situations ought to be allowed as a legitimate goal to avoid the undermining or eradicating of the effect of the law altogether. Second, article 11 of that law stipulates that there is a defence if the distinction is 'required by law'. On this concept too, the preparatory works remain silent. The formulation of the defence in that article is however similar, though not entirely corresponding, to the defence found in the general provisions of Belgian criminal law. Article 70 of the Belgian Criminal Code stipulates that there is no offence if the behaviour was 'prescribed by law' or 'ordered by the government'. In absence of a clarification thereto in the preparatory works of the Anti-Racism Law, it is unclear how article 11 in the Anti-Racism Law should be interpreted in light of article 70 in the Criminal Code.

Furthermore, one may question to what extent the other legal defences known in general criminal law may be applicable in discrimination cases. Unfortunately, no clearcut answer can be provided to that question. The incompatibility of article $4,9^{\circ}$ and article 28 of the Anti-Racism Law leave room for interpretation. Whereas article $4,9^{\circ}$ limits the possibility to raise a legal defence to the situations foreseen in Title II of the law, providing us with the above-mentioned defences in articles 9 and 11, article 28 of the Anti-Racism Law stipulates that all provisions of the general criminal code are applicable to discrimination cases. The latter should mean that not only the legal defences included in Title II can come into play, but also the legal defences included in the general criminal code. In light thereof, 'being legally prescribed' and 'being ordered by the government' as foreseen in article 70 of the Criminal Code should be acceptable. To make matters even more complicated, in Belgian criminal law, there are not only legal defences for which a clear legal basis can be found in the Belgian criminal code, but there are also legal defences that are developed in case law and expressly accepted by our highest constitutional court. The 'state of emergency' is a legal remedy developed by case law which allows you to commit an offence if that is necessary to avoid doing something that is even worse. 
Concluding, taking due account of article 4, $9^{\circ}$ of the Anti-Racism Law, which limits the available legal defences to what is provided for in articles 9 and 11, whilst accepting a small widening effect of the more lenient article 28 Anti-Racism Law, three types of legal defences could be considered as applicable in cases of indirect discrimination based on the nationality of the passengers. First 'the legal prescription' as provided for by article 11 of the Anti-Racism Law, will be analysed taking due account of the interpretation given to the legal prescription included in article 70 of the criminal code. Secondly 'the governmental order' will be analysed, not only using article 70 of the criminal code as a legal basis, but also using article 9 of the Anti-Racism Law which allows for actions that aim to achieve a legitimate goal. In our opinion, following a governmental order could be accepted as the legitimate goal provided for in article 9 of the Anti-Racism Law. Both will be dealt with in one joint section, as they warrant the same conclusion. Thirdly, a similar reasoning can be followed to underpin the applicability of 'the state of emergency' in relation to discrimination. Though no explicit reference is made to it in our antiracism legislation, the recognition of the applicability thereof in Belgian criminal law by our constitutional court justifies it being interpreted as a 'legitimate goal' as foreseen in article 9 of the Anti-Racism Law. In our opinion, accepting both the 'governmental order' and 'the state of emergency' as 'legitimate goals', would not necessarily violate the intended restrictive nature of the applicability of legal defences.

\section{Legal Prescriptions and Governmental Orders: National Fortresses}

As mentioned above, the legal defences 'legal prescription' and 'governemental order' will be dealt with consecutively in this section, as they warrant the same conclusion. When it comes to scoping legal defences, national fortresses are built.

First, the question arises as to whether the indirect distinction made by the airline at the check-in can be justified by qualifying the executive order as the legal requirement/ legal prescription mentioned in article 11 of the Anti-Racism Law. In the preparatory works, no further information is provided about how to interpret the scope of the legal requirement and especially what kind of decisions would fall within its scope. The Explanatory Memorandum merely states that the defence is introduced to avoid that citizens are forced to make a choice between the norms they are to obey. ${ }^{19}$ It is not specified what norms are supposed to be included. In absence of any explanation to that end, the notion 'law' in 'required by law' in article 11 of the Anti-Racism Law, should not

19 Preparatory works of the Belgian Parliament: Parl. St. Kamer, 26 October 2006, 51-2720/1, Proposal for a Law to amend the Law of 30 July 1981 concerning the punishment of acts induced by racism or xenophobia (original text: Wetsontwerp tot wijziging van de wet van 30 juli 1981 tot bestraffing van bepaalde door racisme en xenofobie ingegeven daden) at 53. 
be interpreted differently from the notion 'law' in 'prescribed by law' in article 70 of the criminal code.

In that context, it is generally accepted that 'law', should be interpreted as not only referring to acts that are labelled laws, but as referring to any act that holds a binding prescription issued by the competent governmental authority. In legal doctrine it is further clarified that the governmental authority can be a local, regional or national authority, be it that only Belgian authorities are accepted. ${ }^{20}$ In addition to that, international or European norms can be accepted, provided that they have direct effect, ${ }^{21}$ and there is a tendency to more easily accept the supremacy of international self-executing treaties over the Belgian national laws. Their provisions can also qualify as the binding norms that warrant the use of the defence 'prescribed by law'. ${ }^{22}$ From that perspective, it must be concluded that American norms of whatever type, fall outside that scope, and therefore the Executive Order cannot be successfully relied on to violate a Belgian national criminal law provision and to use this defence. It can be concluded without any reservation that the American Executive Order cannot be the reason to call upon article 11 of the AntiRacism Law and cannot be used to allow the indirect discrimination of passengers.

Second, the question arises whether the indirect distinction can be justified using 'the governmental order' as a defence. The application of the governmental order as foreseen in article 70 of the Criminal Code should in our view be accepted as acting towards a legitimate goal as foreseen in article 9 of the Anti-Racism Law. The legitimate goal would then be to obey the orders made by the executive branch. Such an interpretation would allow the use of the general legal defence in the specific anti-racism context. It would constitute a compromise between on the one hand article $4,9^{\circ}$ of the Anti-Racism Law, that limits the possible defences to the ones listed in Title II of the Anti-Racism Law, and on the other hand, article 28 of that same Anti-Racism Law, which allows for the application of the general provisions of Belgian criminal law. As the legislator failed to provide us with any further indications as to how to interpret 'legitimate goal, it is our opinion that an interpretation to apply a generally accepted defence would not unacceptably undermine the effectiveness and intended limiting character of the said provisions.

20 Witters and Verhelst, Nieuwe discriminatieregels in arbeidszaken (New discrimination rules in labour cases), 7 Oriëntatie (2007) at 176.

${ }_{21}$ Vanhoudt and Calewaert, Belgisch strafrecht, Tweede boekdeel (Belgian criminal law, Second part) (Story-Scientia 1976) at 423; Dupont, Beginsel van strafrecht (Principles of Criminal Law), Volume 1 (Acco 1983) at 158; Van den Wyngaert, Strafrecht en Strafprocesrecht in hoofdlijnen (Criminal law and Criminal procedural law, main principles) (Maklu 2014) at 250; Verbruggen and Verstraeten, Strafrecht en strafprocesrecht voor bachelors, Deel I (Criminal law and Criminal Procedural law for bachelor students) (Maklu 2016) at 61.

22 Court de Cassation (Belgium) 27 May 1971, Pas. 1971, 1, 886. 
To successfully rely on the defence 'governmental order', the order should be (i) lawful and (ii) coming from the legitimate government. ${ }^{23}$ Firstly, accepting only 'lawful' orders aims at avoiding that unjust situations become just, simply because they are ordered by a governmental actor. ${ }^{24}$ The defence can only be used in relation to orders that come from a governmental actor that stayed within the boundaries of its competences. ${ }^{25}$ It goes without saying that the lawfulness of the American Executive Order is not uncontested. Many have argued that the President lacked the competence to take such a decision. Given the massive amount of media attention, it would be erroneous to allow an airline company to successfully argue not to be aware of possible objections regarding the lawfulness of the order. Furthermore, the possible unlawful nature of the American Executive Order is not the only obstacle for the success of this defence. For the defence to be successful, it is required that the order is issued by a legitimate government, under which only orders issued by persons having power vested in them by Belgian public law are accepted. ${ }^{26}$ Therefore only orders issued by Belgian governments are accepted. ${ }^{27}$ The American Executive Order can never qualify as a governmental order that allows ignoring provisions of Belgian criminal law. For that reason, it is our opinion that an airline company operating from the Belgian Brussels National Airport can never successfully rely on the defence 'governmental order' to avoid criminal prosecution for violating the provisions of the Anti-Racism Law.

The scoping of both legal defences demonstrates that when it comes to defining national criminal law and allowing exceptions thereto, national fortresses are built. Criminal law is said to be highly sensitive and telling for a country's national identity. Only in very exceptional cases countries agree to derogate from that rule. And those derogations are always very limited in scope. Even the scope of the mutual recognition principle introduced as the corner stone of judicial cooperation between European Union member states does not stretch this far. The scoping clarifies that only national law and national orders can be used as a basis to call upon a legal defence. Foreign laws or orders are not acceptable. The water between the own and the American societal views is too deep to cross. Even within the European Union the co-existance of different national criminal codes (resulting from those different societal views) is tolerated, but only to the extent that those differences do not impact upon the national criminal codes; foreign

23 Van den Wyngaert 2014 at 258-259; De Nauw and Deruyck, Overzicht van het Belgisch Algemeen Strafrecht (Overview of the Belgian General Criminal Law) (Die Keure 2015) at 76; Vandermeersch, Eléments de droit pénal et de procédure pénale (Elements of the criminal law and criminal procedural law) (la Charte 2015) at 107.

$24 \quad$ Dupont 1983 at 159.

$25 \quad$ Van den Wyngaert 2014 at 258.

26 Dupont 1983 at 159; Court of First Instance Liège (Belgium) 25 April 1963, J.T. 1963, 385.

$27 \quad$ Van den Wyngaert 2014 at 259. 
judicial decisions are recognised and executed across borders, but only to the extent that they are compatible with the national criminal code.

\section{The State of Emergency}

\subsection{Starting Points}

A third option would be to counter the indirect distinction by arguing that a choice had to be made between two evils, and the lesser evil of the two was chosen. This situation is underpinned by the defence 'state of emergency', that has no legal basis in Belgium, but is developed in case law ${ }^{28}$ and recognised by our Court de Cassation. ${ }^{29}$ It is introduced as a general defence ${ }^{30}$ that comes into play when there is a conflict between two legal goods, one of which can only be protected by violating the other. ${ }^{31}$

Four conditions need to be met. Firstly, the proportionality of the behaviour is scrutinised. There will be no offence if someone is forced to make a choice between two legal goods and sacrifices the legal good of the lesser value. ${ }^{32}$ Protecting the legal good of the lesser value would be considered disproportionate. Determining the value of legal goods can be quite challenging. In its current case law, the Court de Cassation is lenient in its interpretation, especially when it is not clear or when it is difficult to determine which of the protected legal goods is of the lesser value. ${ }^{33}$ Secondly, the subsidiarity of the behaviour is scrutinised. ${ }^{34}$ Committing the offence and thus violating the legal good

28 Dupont 1983 at 168; De Nauw and Deruyck 2015 at 79; Vandermeersch 2015 at 92 . At the occasion of the discussions relating to the preparation of a new criminal code, it has been suggested to introduce a clear legal basis for the state of emergency. Rozie and Vandermeersch, Commissie voor de Hervorming van het Strafrecht. Voorstel van voorontwerp van Boek I van het Strafwetboek (Commission for the Reform of the Criminal Law. Proposal for a draft of book I of the Criminal Code) (Die Keure 2016) at 64.

29 Court de Cassation (Belgium) 13 May 1987, RCJB 1989 at 588 with an annotation of De Nauw, La consécration jurisprudentielle de létat de nécessité.

30 Monballyu, Zes eeuwen strafrecht. De geschiedenis van het Belgische strafrecht (1400-2000) (Six centuries of Criminal Law. The history of the Belgian Criminal Law 1400-2000) (Acco 2006) at 119.

31 Monballyu 2006 at 115; Vandermeersch 2015 at 92; De Nauw and Deruyck 2015 at 80; It is proposed to maintain this principle in the future criminal code. Rozie and Vandermeersch 2016 at 64 .

$32 \quad$ Dupont 1983 at 167; Vandermeersch 2015 at 93.

33 Court de Cassation (Belgium) 24 January 2007, Pas. 2007, 167; Court de Cassation (Belgium) 5 April 1996, Pas. 1996, I, 283. It is suggested to make this condition more strict in the future criminal code. Rozie and Vandermeersch 2016 at 65.

$34 \quad$ Vandermeersch 2015 at 94. 
of the lesser value should have been the only possible way to protect the legal good with the higher value. ${ }^{35}$ Thirdly, the position of the person involved is scrutinised. Relying on 'state of emergency' as a defence is only acceptable if the person involved is not himself responsible for that state of emergency and thus for the conflict between legal goods. ${ }^{36}$ Our Court de Cassation is quite strict on the interpretation of that third requirement having only recently reiterated that there can be no 'state of emergency' if the person himself is responsible for the precarious situation. ${ }^{37}$ Fourthly, the final condition relates to the proximity between the choice, the act and the danger for the legal goods involved. The danger should be acute, sufficiently significant and either exist or occur immediately. ${ }^{38}$

In essence, the question is whether there could be such a state of emergency that would amount to a defence and thus justification to leave passengers behind without that qualifying as a discrimination offence. It would mean that leaving the passengers behind and thus knowingly discriminating against them, would still be better than to take the passengers along, and thus putting the airline company in an acute and significant danger of some sort, that would be even worse. That questions links in nicely with the second concern voiced to us by the airline company. Concerns were voiced that ignoring the order and taking the passengers along as suggested by some protesters, would possibly amount to a form of people smuggling. That concern was based on the idea that facilitating the entry of someone into a state not very keen on welcoming them, would put them right at the heart of that offence. In light thereof, it should first be assessed to what extent accepting passengers would amount to people smuggling, and second, to what extent people smuggling constitutes the higher legal good, i.e. that the choice is proportionate for discrimination is the lesser evil of the two. Mirroring that reasoning, the analysis will be repeated in light of the financial arguments that have been raised. Especially in written media, airline companies have pointed to the tremendous financial penalties that would be imposed should they ignore the Executive Order and accept passengers of the listed nationalities. This argument was used to their defence for acting along with the American President and executing a so-called 'immoral and unethical' order.

In relation to the discussion to either or not execute the travel ban, there are two possible scenarios that warrant calling upon the state of emergency. Firstly, it is valid to question the extent to which people smuggling could come into play when an airline company would ignore the Executive Order. Secondly, it is equally valid to fear the financial consequences of ignoring the Executive Order. Particularly this second concern has attained a central position in the public reactions of airline companies. Both scenarios

35 De Nauw and Deruyck 2015 at 80.

36 De Nauw and Deruyck 2015 at 81, with reference to Court de Cassation (Belgium) 13 November 2001, Arr. Cass. 2001, nr. 613, concl. Adv. Gen. M. de Swaef; Vandermeersch 2015 at 95.

37 Court de Cassation (Belgium) 4 March 2014, AR P.13.1775.N.

38 Monballyu 2006 at 119; De Nauw and Deruyck 2015 at 80; Vandermeersch 2015 at 94. 
could potentially warrant the choice to go ahead with executing the Executive Order and knowingly discriminating travellers.

\subsection{Discrimination vs People Smuggling}

It is clear that not only obeying the Executive Order can be problematic in light of both anti-racism and/or criminal law. It appears relevant to also look into the consequences of disobeying the Executive Order, because that too can also place airline companies within the scope of legal provisions. Differently put, the question arises whether allowing passengers to travel along despite the travel ban would constitute an offence. In relation to this, the question arises whether transporting passengers to the United States - against the provisions of the Executive Order - whilst knowing that these passengers are not in the possession of the required travel documents, constitutes a form of people smuggling. If so, a second question arises, more specifically whether this possibly is the state of emergency needed in defence of committing the discrimination when executing the Executive Order. In sum, if so, airline companies would then choose to discriminate their travellers in order not to smuggle them.

Firstly, it should be pointed out that as of 2005 the criminal law provisions included in the Belgian Alien $\mathrm{Act}^{39}$ differentiate between the offence of 'people smuggling' and the lesser offence of 'assisting in illegal migration'.$^{40}$ Article 77 of the Belgian Alien Act comprises the offence of assisting in illegal migration, stipulating that:

He who knowingly and willingly assists or attempts to assist a person, not a national of any of the members states of the European Union, to either enter or stay in or travel through the territory of a State, in violation of the local legislation of that State, or he who prepares or facilitates that entry, stay or travel through, will be punished with a

39 Law of 15 December 1980 on entry, stay, settlement and removal of foreign nationals (wet betreffende de toegang tot het grondgebied, het verblijf, de vestiging en de verwijdering van vreemdelingen), Belgian Official Journal (31 December 1980) at 14584.

$40 \quad$ Vermeulen and Arnou, Nieuwe Belgische strafwetgeving tegen mensenhandel, mensensmokkel en huisjesmelkerij (New Belgian Criminal law provisions against trafficking in persons, people smuggling and exploitation of tenants) at 53-107 in Arnou et al., Strafrecht en strafprocesrecht, XXXIIste Postuniversitaire cyclus Willy Delva (Criminal law and Criminal Procedural law. 32nd edition of the post university permanent training module in honour of Willy Delva) (Kluwer 2006). 
prison sentence of eight days up to one year and a financial penalty of one thousand seven hundred up to six thousand euros, or one of these sentences alone. ${ }^{41}$

The fundamental difference with article 77bis of the Belgian Alien Act, relates to the envisioned financial benefit. ${ }^{42}$ Article $77 b i s$ stipulates that the more severe offence of people smuggling consists of:

\begin{abstract}
... contributing, in any way, directly or via a middle man, to the entry, transit or stay of a person, who is not a national of any of the member states of the European Union, against the laws of that State, with a view to obtaining, directly or indirectly a financial benefit. This offence is punished with one up to five years of imprisonment and a financial penalty of five hundred to fifty thousand euros.
\end{abstract}

That distinction corresponds entiretly with the definitions prescribed by EU law. The Decision 2002/90/EC on the facilitation of unauthorised entry, transit and residence includes both offences. ${ }^{43}$ Article 1.1 (a) relates to any person who intentionally assists a person who is not a national of a Member State to enter, or transit across, the territory of a Member State in breach of the laws of the State concerned on the entry or transit of aliens. Article 1.1 (b) relates to any person who, for financial gain, intentionally assists a person who is not a national of a Member State to reside within the territory of a Member State in breach of the laws of the State concerned on the residence of aliens.

Based on the definitions, it is practically impossible to rule out that disobeying the Executive Order and thus taking passengers along to the United States, would qualify as assisting with illegal migration as included in article 77 of the Belgian Alien Act or article 1.1 (a) of Decision 2002/90/EC. After all, the airline company knowingly and willingly assists passengers of one of the six listed countries to enter into the United States, despite not being in the possession of the required travel documents, which is clearly in violation

$41 \quad$ Original text: 'Hij die wetens en willens een persoon die geen onderdaan is van een lidstaat van de Europese Unie helpt of poogt te helpen het grondgebied van ... Staat ..., binnen te komen of aldaar te verblijven, dan wel erdoor te reizen, zulks in strijd met de wetgeving van deze Staat, hetzij in de handelingen die de binnenkomst, de doorreis of het verblijf voorbereid hebben of ze vergemakkelijkt hebben, hetzij in de feiten die ze voltooid hebben, wordt gestraft met gevangenisstraf van acht dagen tot een jaar en met geldboete van zeventienhonderd euro tot zesduizend euro, of met een van die straffen alleen'.

42 Preparatory works of the Belgian Parliament: Parl. St. Kamer, 14 January 2005, 51-1560/1, Proposal to change several legal provisions to strengthen the fight against trafficking in human beings and people smuggling (Wetsontwerp tot wijziging van diverse bepalingen met het oog op de versterking van de strijd tegen mensenhandel en mensensmokkel) at 45 .

43 Decision 2002/90/EC of 28 November 2002 defining the facilitation of unauthorised entry, transit and residence, O.J. L 328 of 05/12/2002 (hereafter Decision 2002/90/EC). 
of the Executive Order and thus the laws of the destination country. The question whether the choice of the airline company would amount to the more severe offence of people smuggling, depends on the way 'financial benefit' is defined. In other words, knowing whether their behaviour constitutes people smuggling, depends on whether or not having a paying traveller on board would amount to providing them with the required financial benefit. Neither the preparatory works of the Belgian Alien Act nor those of Decision 2002/90/EC contain any indications or guidelines on how to interpret the concept of financial benefit. ${ }^{44}$

At first sight, the constituent elements of article $77 b i s$ of the Belgian Alien Act are intended to be relatively low, given that any contribution, in whatever way, directly or via a middleman, of a person entering the territory of a state amounts to the offence. From that perspective, it could be presumed that also the financial benefit should be interpreted as constituting a low threshold. And thus the benefits following from paying the ticket would suffice. However, it should be noted that first, the legislator intended to create a significant difference between assisting in illegal migration and smuggling and second, that the financial benefit is not included in the definition of trafficking in persons ${ }^{45}$ testifying to the importance the legislator has given to that constituent element when it comes to people smuggling. It is clearly intended to limit the scope of the offence to situations where there is a clear financial benefit. In absence thereof, the facts will be treated as assisting in illegal migration. Without clear guidelines in the preparatory works, there is no reason to presume that the constituent element here needs to be interpreted different from the same constituent element found in the offence of participation in a criminal organisation. During the preparation of that offence, a discussion was held in the Parliament clarifying that it could relate to any patrimonial benefit, received directly or indirectly following the commission of the offence. ${ }^{46}$ Still in that context, it was argued that there is no reason to distinguish the benefit in the offence definition from the benefits that can fall within the scope of the benefits that are up for confiscation pursuant to article $42,3^{\circ}$ of the Criminal Code. The nature of the benefit (be it mobile or immobile, material or immaterial) is of no importance. ${ }^{47}$

The difficulty in the interpretation of the required financial benefits in the present case stems from the fact that travellers have bought a plane ticket and have thus paid the airline company, which constituted a financial benefit. In our opinion there is some room for interpretation as to whether that (potentially rather small) benefit is sufficient

44 No explanation or guidelines are provided in the preparatory works of the Belgian Parliament: Parl. St. Kamer 51-1560, nor in the Preparatory works of the Belgian Senate: Parl. Hand. Senaat 3-1138.

$45 \quad$ Articles 433 quinquies and following of the Belgian Criminal Code.

46 Preparatory works of the Belgian Parliament: Parl. St. Kamer, 98-99, 49-954/17, p. 30.

47 Preparatory works of the Belgian Parliament: Parl. St. Kamer, 89-90, 987/1, p. 8. 
to qualify as a benefit related to smuggling. It could also be argued that an additional financial benefit is required to distinguish between the 'normal' benefit that is related to the transport of regular passengers and the 'additional' benefit that is related to the actual smuggling. Differently put, should the passengers of the said countries have paid an extra amount to be smuggled, or is the original ticket sufficient? One must take due account of the intention of the legislator, and consider that (i) the idea was to clearly distinguish between smuggling and the lesser assisting in illegal migration and (ii) the financial benefit is not directly linked to the intention to smuggle people. In doing so, it is our opinion that the behaviour of an airline company who would ignore the Executive Order and allow the passengers on board would not commit the offence of people smuggling, but would commit the lesser offence of assisting in illegal migration. In our opinion, an additional specific benefit is required, although at the same time it cannot be ruled out that a trial judge would be of a different opinion.

The choice between the two offences to qualify the taking along of the passengers may proove to be crucial in determining which of the behaviours (taking passengers along or leaving passengers behind) is the lesser offence. Notwithstanding the difficulty and uncertainty in qualifying the behaviour of a disobedient airline company as people smuggling, the qualification of assisting in illegal migration will always stand. This means that the state of emergency relates to either committing the offence of indirect discrimination when obeying the Executive Order and leaving the passengers behind or committing the offence of assisting in illegal migration when disobeying the Executive Order and taking the passengers along. The state of emergency is designed to find a pathway out of this dire situation and allow citizens to commit the lesser offence to avoid having to commit the more severe offence. Therefore, the question arises whether the airline company should obey and discriminate in order to avoid having to smuggle or whether the airline company should disobey and smuggle in order to avoid having to discriminate. The final decision will be left to the trial judge, who would base his decision on the identification of the lesser offence either on the extent to which the behaviour fits within the boundaries of the offence and/or the severity of the offences based on the sentences provided for. ${ }^{48}$ Though the difference is not very significant, considering that discrimination is punishable with imprisonment of one month up to one year whereas assisting in illegal migration 'only' with imprisonment of eight days up to one year, would suggest that assisting in illegal migration is the lesser offence. This would mean that the airline would have to assist in illegal migration in order to avoid committing the more severe offence of discrimination. If the severity of the act of taking passengers along is stretched up to constitute the more severe offence of people smuggling, the conclusion would be different. In that case, the comparison would result in the airline company 
having to discriminate in order to avoid committing the more severe offence of people smuggling.

More importantly, even though commercially and economically not an option to consider lightly, the judge may come to the conclusion that committing either of the offences was not the only way out of this difficult situation. It should be recalled that the subsidiarity of the behaviour is scrutinised as a conditio sine qua non the legal defence of state of emergency can be relied on. ${ }^{49}$ Committing the offence and thus violating the legal good of the lesser value should have been the only possible way to protect the legal good with the higher value. ${ }^{50} \mathrm{He}$ may come to the conclusion that committing either of the offences was easy to avoid by simply not flying at all. By cancelling the transatlantic flights to the United States, the airline company would not discriminate nor smuggle. Such a decision could both positively and negatively impact upon their image and therefore have significant financial implications. The risk for financial implications is not limited to reputational damage due to cancelling the flights. Both discrimination and smuggling are punished with financial penalties and more importantly, allowing passengers to travel to the United States in violation of the Executive Order, is also punished with severe financial penalties at the US side, in addition of which airline companies violating the immigration rules run the risk of losing the landing licences. For that reason, it is valid to include the financial implications in the reasoning and analysis of the applicability of the state of emergency.

\subsection{Discrimination vs Bankruptcy}

Finally, based on the above analysis and the core of the reactions from the aviation sector in the media, the question arises whether 'protecting the airline company for the financial penalties' linked to disobeying the Executive order (and thus knowingly and willingly accepting passengers that are not in the possession of the required travel documents) could be the legitimate goal used as a legal defence to justify making an indirect distinction. From that perspective, the airline companies would discriminate in order to avoid a financial hangover. The viability of such argumentation is based on the nature of the financial hangover. The reactions in the media make reference of very divers financial consequences. In light thereof, it is highly relevant to look into the financial risks, in order to precisely determine the nature of the financial hangover and the risk related to it.

\footnotetext{
$49 \quad$ Vandermeersch 2015 at 94.

50 De Nauw and Deruyck 2015 at 80.
} 
Firstly, there is a penalty linked to transporting to the United States passengers who are not in the possession of the required travel documents. Section 273 of the American Immigration and Nationality Act explains that:

It shall be unlawful for any person, including any transportation company, or the owner, master, commanding officer, agent, charterer, or consignee of any vessel or aircraft, to bring to the United States from any place outside thereof (other than from foreign contiguous territory) any alien who does not have a valid passport and an unexpired visa, if a visa was required under this Act or regulations issued thereunder.

And:

If it appears to the satisfaction of the Attorney General that any alien has been so brought, such person, or transportation company, or the master, commanding officer, agent, owner, charterer, or consignee of any such vessel or aircraft, shall pay to the Commissioner a fine of $\$ 3,000$ for each alien so brought ...

Secondly, violating the American Immigration and Nationality Act could also have implications for the rights of airline companies to land on American Territory. The aviation agreements contain provisions on suspending and lifting the rights to land. Such a provision is included for example in the aviation agreement between the EU and the US. ${ }^{51}$ This means that the concerns expressed by the airline companies to have their hands tied and be in the absolute impossibility to disobey the Executive Order despite possible ethical problems with the execution thereof, are valid. ${ }^{52}$

The question now arises whether the financial consequences are of a nature that would allow airline companies to violate the Anti-Racism Laws and thus to discriminate passengers in order to protect their financial interests. This specific question has not yet been ruled on in Belgian case law. What has been ruled on is the weighing of financial risks that would amount to bankruptcy versus violations of other (criminal law) provisions. An imminent bankruptcy can be used as a defence to commit some offences. ${ }^{53}$

$51 \quad$ Article 5.1 c) juncto article 7.2 of the Air Transport Agreement between the European Community and its Member States on the one hand and the United States of America on the other hand, Brussels 25 April 2007 and Washington 30 April 2007, Belgian Official Journal 11 September 2013 at 64132.

52 See amongst others: https://www.nhnieuws.nl/nieuws/199485/klm-vreest-voor-financilegevolgen-van-inreisverbod-trump (last consultation 25 January 2018) and https://www. businessinsider.nl/klm-werkt-mee-aan-inreisverbod-trump-omdat-anders-miljoenenboetesdreigen/ (last consultation 25 January 2018).

53 Court of First Instance Brussels (Belgium) 17 December 1986, J.T. 1987, 127. 
The court of appeal of Ghent ruled that a business man was allowed to violate environmental law provisions when it was clear that installing the required cleaning and purifying installations would de facto have led to the demise of the company. ${ }^{54}$ Even though the Belgian case law has ruled that financial risks could be used in defence of committing some offences, it does not mean that any financial risk, even not any bankruptcy, would be acceptable as a defence in relation to any kind of offence. Some offences are related to legal goods that are of such importance that no other legal good could be used as a defence. The fact that a possible bankruptcy is not to be interpreted as a free pass to commit offences, becomes apparent from the case law on the violation of labour law provisions in relation to the wages of employees. ${ }^{55}$ The court of first instance in Charleroi, ${ }^{56}$ as affirmed by the court of appeal of Liege, ${ }^{57}$ has clearly ruled that a potential bankruptcy cannot be used as part of the state of emergency in defence of violating the said labour law provisions. The court explained that in any event the protected legal goods should be balanced and that in this case the rights of the employees outweighed the possible continuation of the business. The interest of the employees was rated more important than the interest of the shareholders. A different interpretation would be equal to the demise of the established social order. ${ }^{58}$

What is absolutely clear, however, is that the risk of possible financial consequences is insufficient. The application of the state of emergency in defence of having committed an offence requires an actual, eminent and serious danger for the protected legal good..$^{59}$ A risk that is further away or can be imagined without certainty of it materialising is not sufficient. The question therefore arises whether the possible fines to be imposed following a possible criminal procedure afterwards, and the possibility of having an administrative procedure that would revoke their rights to land, would qualify as a sufficiently actual, eminent, and serious danger. The court of appeal of Brussels has ruled in this regard, that the necessity to act in order to avoid bankruptcy can only be justified if the risk is especially threatening with the certainty of having the dreaded result. ${ }^{60}$

Therefore, it is our opinion that, in order to successfully use the argument to discriminate in order to avoid the financial penalties originating from disobeying the Executive Order, the airline company must be able to demonstrate that the risk of a bankruptcy is actual, imminent and likely to materialise. The analysis of the case law

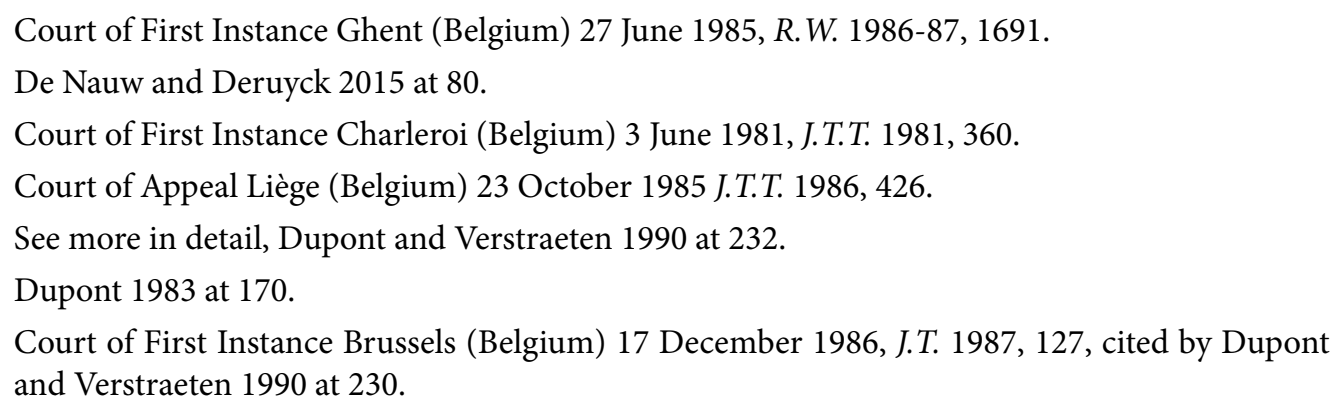


clearly supports the conclusion that the state of emergency would only be successful if the demise of the company is immediately in danger. Calling upon the state of emergency will only be successful if the bankruptcy is imminent, and moreover that this is a consequence of obeying a rule whilst at the same time it is perfectly clear that this is a consequence that is unintended by the legislator. ${ }^{61}$

In addition to our concerns related to the extent of the financial penalties and the likeliness of the materialisation of that effect, we need to again point to the fact that the state of emergency is only accepted when the person involved had no other option but to violate the incumbent provisions. ${ }^{62}$ Again, the question arises whether the problems stemming from the financial penalties cannot be avoided by simply cancelling the transatlantic flights to the US. In light of this possibility, the question should then be rephrased into the question as to what extent such a cancellation option would in itself give rise to such significant financial consequences that it would equally result in a bankruptcy. That analysis should look into the particularities of the flight schedule of each individual airline company as it will significantly differ. It seems however relatively unlikely that an airline company would risk bankruptcy based on the temporary cancellation of the transatlantic flights. At the same time, the latest events in relation to this have demonstrated that the travel ban is far from being lifted. Donald Trump has announced to sign yet another Executive Order, holding a slightly modified version of the travel ban.

\section{Conclusion: Checkmate at the Check-In}

An airline company operating from Brussels National Airport, be it SAS or any other airline company, and denying passengers access to the plane because they are - pursuant to the American Executive Order - not in the possession of the required travel documents, makes an indirect distinction based on nationality as foreseen in article $4,8^{\circ}$ of the Belgian Anti-Racism Law. Denying access for not being in the possession of the required travel documets is 'a seemingly neutral rule that would have an especially negative impact on people protected based on any of the listed criteria'. Should that same airline company decide to disobey the Executive Order and take the passengers along, it still runs the risk of placing itself within the scope of assisting in illegal migration at the least, possibly even smuggling of people. Even though it is - in our opinion - very unlikely that a trial judge

61 Van Volsem and Meganck, Milieurecht en straf(proces)recht: een aantal bedenkingen met onder meer aandacht voor de strafrechtelijke aansprakelijkheid van rechtspersonen (Environmental law and criminal (procedural) law: a number of considerations taking account of the criminal liability of legal persons), 6 TMR (2008) at 750.

62 Dupont 1983 at 167; Verbruggen and Verstraeten 2016 at 66. 
would accept having sold the ticket as having obtained the required financial benefit, a qualification as people smuggling cannot be completely ruled out. The question put to us by one of the airline companies to look into the legal impact of the travel ban from a criminal law perspective is more than valid.

The search of a way out of the checkmate position has raised far more questions and discussion points than it answered or clarified. The first batch of questions and discussion points relate to the European legal basis to prohibit discrimination based on nationality. It turns out that both at EU level as well as at Council of Europe level steps have been taken, but no full fledged legal framework to organise a general protection is in place. Taking account of the overarching European intention of protecting human rights and promoting equality, a more forceful legal framework is long overdue.

The second batch of questions and discussion points relate to the types of legal defences that can be used in anti-racism cases. Traditionally, the European legislator (both at EU as well as at Council of Europe level) remains silent on the acceptability to use a legal defence to get away with behaviour targeted in (criminal) law provisions. The question arises whether - when it comes to fundamental European values such as non-discrimination and equality - the time has not come to express a clear European view on this. In absence thereof, it is up to the individual member states to regulate to what extent legal defences exist. National legislations are not free from inconsistencies, unclarities at the least, on that point. The puzzle of possible legal defences in the Belgian legal framework is not self-explanatory and the pieces at times feel to belong to different puzzles.

The third batch of questions and discussion points relate to the scope of possible legal defences. Even though many may feel as though in the current situation an airline company must be able to seek recourse to some sort of legal defence, even a very lenient interpretation of the available legal defences that are supposed to be interpreted strictly, cannot rule out that obeying the travel ban qualifies as an indirect discrimination. An argumentation that is based on the idea that it is necessary to discriminate in order not to smuggle the people involved, is filled with weaknesses. Not only can it not be guaranteed that non-discrimination is the lesser offence (meaning that it is better to discriminate as opposed to smuggle the people), the most important weakness in the argumentation is the subsidiarity element. The state of emergency allows for offences to be committed, but only if committing the offence is the only way out. It can therefore be questioned whether the flights should not have been cancelled to avoid any of the above problems. The only way to counter the cancellation option, is by arguing that cancellation in itself can never be an option because it would result in the bankruptcy of the airline company, an argument that is still dependent on the option of the judge that saving the airline from bankruptcy is more important than saving the passengers from either discrimination or 
smuggling. The existing case law on the possibility to use financial arguments when using the state of emergency as a legal defence is inconclusive on this point.

Checkmate at the check-in appears to be the conclusion that has to be drawn. Cancelling the flights seems to be the safest option, even though that is not the answer airline companies were looking for. If anything, this case shows that the legal questions raised by the airline companies are not in vain. It is somewhat disappointing that many European governments sufficed in arguing that the travel ban is part of the sovereign American policy on migration, which is and should remain a matter for the American government to decide on. Our prime minister commented that the American migration policy is not in line with the Belgian views on migration and that in no case we would use the American Executive Order as an example or source of inspiration to further shape our own migration policies. ${ }^{63}$ It goes without saying that such statement does not do anything to mitigate the valid concerns raised by the airline companies. Surely the Belgian legal system is not the only one holding these kinds of provisions on anti-racism and discrimination based on nationality on the one hand and assisting in illegal immigration and people smuggling on the other hand. The globalisation has resulted in more and more companies (in this case airline companies) who find themselves confronted with the consequences of the incompatibilities between different legal systems. A more clear position including a legal framework to interpret the issues raised would be more than welcome. January 2018); https://www.tijd.be/politiek-economie/belgie-algemeen/Premier-Michel-Belgieis-het-oneens-met-inreisverbod-VS/9856986? ckc=1\&ts=1506087227 (last consultation 25 January 2018); http://www.hln.be/hln/nl/957/Binnenland/article/detail/3066739/2017/01/29/ Premier-Michel-reageert-op-inreisverbod-Trump-Belgie-is-het-oneens-en-zal-er-geenvoorbeeld-aan-nemen.dhtml (last consultation 25 January 2018). 